\title{
From Infinitives to Deverbal Nominals in the Language of Orkhon Inscriptions
}

\author{
Aysel Ahmadova \\ Department of Ancient Languages and Cultures, Azerbaijan National Academy of Sciences Institute of \\ Linguistics, Azerbaijan
}

\begin{abstract}
Although inflection and derivation are two different morphological processes, there is not a strict distinction between them. Even in the modern Turkic languages some inflectional suffixes can be used for wordformation purposes and vice versa. Diachronic analysis of Orkhon Inscriptions and modern Turkic languages illustrates transformation processes from inflectional to derivational suffixes. However, it is not the only possibility, because with the increase in productivity and grammaticalization of meaning, derivational suffixes, especially deverbal nominal-forming suffixes in the language of Orkhon Inscriptions began to be used as the means of verbal inflection in the modern Turkic languages. This article focuses on the grammaticalization of the deverbal nominal suffixes in Turkic languages, and argues that the beginning of this process was registered in the language Orkhon Inscriptions. This study aims to prove that suffixes of infinitive were originally derivative suffixes making nouns and adjectives from verbs.
\end{abstract}

Keywords - Derivation, Grammaticalization, Inflection, Lexicalization, Old Turkic, Turkic Languages

\section{INTRODUCTION}

Being among the oldest written monuments of Turkic languages, Orkhon Inscriptions are very important for turkological studies. The language of the Inscriptions demonstrates some interesting wordformation features like lexicalization and grammaticalization of derivative suffixes. These processes are found especially in deverbal noun- and adjective-forming suffixes. Analyses show that some of the deverbal derivative suffixes are used as the suffixes of infinitive. The suffix - $i \check{\text { š }}$, for example, is one of the most productive nounforming suffixes in modern Turkic languages, though the development of this morpheme was not that smooth. It comes from the suffix of reciprocal voice. However, it later turned into the suffix of noun-formation, and finally, became the suffix of verbal nouns in modern Turkic languages.

\section{FROM DEVERBAL NOUNS TO VERBAL NOUNS}

The suffix $-i \check{s}$ is an example of lexicalization in Orkhon Inscriptions. -ï̌ came from the suffix of reciprocal voice. There are a lot of nouns in modern Turkic languages that are formed by the means of the suffix $-i \check{S}$, and they have various meanings. But the number of the nouns with this suffix is very restricted in Orkhon Inscriptions, and they are identical to one another for their meanings, three of them have the meaning 'war, fight', which is the name of the reciprocal process. And it proves that the suffix -ïs itself has reciprocal meaning. For instance, the noun uruš means 'war, fight', but its root, the verb ur-, only means 'to beat', i.e. it does not have any reciprocal meaning. So we can assume that the element that gives reciprocal meaning to this word is the suffix -uš. It proves the claim that $-i \check{s}$ originated from the morpheme of reciprocal voice. The language of Orkhon Inscriptions reflects this process perfectly.

The investigation of the word-formation processes in Turkic languages from Orkhon Inscriptions to modern Turkic languages helps identify three stages in the development of the suffix -ǐs. These are given below:

1. It occurs only in the nouns that are homonyms with the verbs. In this stage, the words with $-i \check{s}$ depicted the names of reciprocal processes.

2. It is used as an independent noun forming suffix. In this stage the nouns with -ï̌ depicts not only the name of process, but also the name of the person, the argument of the process, the result of the process and so on. Most of these words did not even have reciprocal meaning.

3. It is used as the suffix of verbal nouns. In this stage, $-i \check{s}$ came closer to grammatical suffixes, and was able to be added to every verb.

The first stage is reflected in the language of Orkhon Inscriptions, the second one cover the period starting from the Middle Ages, while the last one continues in some modern Turkic language, such as Uighur, Uzbek, Turkmen, Kirgiz, Altai, and Turkish. 
As it was mentioned above, there are few nouns formed with the suffix - $i \check{s}$ in the language of Orkhon Inscriptions. It would be useful to analyze these nouns before giving the examples from modern Turkic languages:

1. Uruš 'fight, war'. This noun was registered only in one example:

Eb-kä täg-dük-im uruš qïl-ïp (Ongin front 10)

Home-DAT reach-PTCP-POSS.1.SG fight do-PST

'I fought when I reached home'

This word comes from the verb ur- 'to beat', and it is the homonym of the verb uruš- 'to fight' [1: 616]. Though uruš was not used as a verb in Orkhon Inscriptions, it occurs in the later stages of the Turkic languages. It makes us to think that the verb uruš- was already used in the $8^{\text {th }}$ century, but was not registered in the Inscriptions because of the small number of monuments. In Oghuzname, the written material of the $13^{\text {th }}$ century the noun uruš $\gamma u$ is used instead of uruš [1: 616]. It proves that uruš was considered as a word depicting a motion, not a name of a process.

2. Sü̈üs 'fight, war'. This noun is registered only five times in the inscription of Kuli Chor:

Besbaliq-da tört süyüs süyüs-dük-dä Küli čor opla-yu tägip bulya-yu... (Kuli chor 11)

Besbalik-LOC four fight fight-PTCP-LOC Kuli Chor rush-CVB reach-CVB

mix up-CVB...

'When they fought four times in Besbalik, Kuli Chor reached quickly and mixed up...'

Sü̈üs bol-sar, čäri-g it-är er-ti... (Kuli Chor 9)

War be-COND army send-FUT AUX-PST...

'If there is a war, he would send an army...'

However, its verbal homonym was wide-spread in Orkon Turkic:

...qayan-ïn birlä Sona yïš-da sü̈üš-di-m (Bilge Kaghan east 26-27)

...kaghan-POSS.3.SG with Sona forest-LOC fight-PST-1.SG

'I fought with their kaghan in the Shantun forest'

...alp-ïn üčün Tabyač-qa yeti yegirmi süyüs-di,

Qïtay-qa yeti sünüs-di, oyuz-qa bis sünüs-di (Tonukuk 49)

...gallant-3.SG for Tabghach-DAT seven twenty fight-PST

Kitay-DAT seven fight-PST oghuz-DAT five fight-PST

'....as he was gallant, he fought seventeen times against Tabghach, seven times against Kitay, five times against Oghuz'

It is not clear from what word exactly sünüš was formed, but it is known that the root of this word is

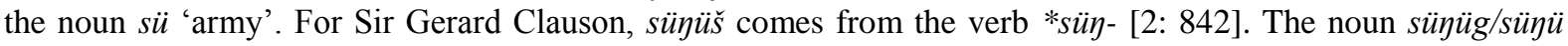
'spear' [1: 517] also formed from the same verb. Kul Tigin:

3. Tägiš 'encounter with the enemy, fight'. This word is used only in one example in the inscription of

$\begin{array}{lllll}\text { Sü } & \text { tägis-in-tä } & \text { yitinč } & \text { är-ig } & \text { qïlïčla-dï (Kul Tigin north 5) } \\ \text { Army } & \text { encounter-3.SG-LOC } & \text { seventh } & \text { man-ACC } & \text { sabre-PST }\end{array}$

'He sabred the seventh man in the encounter of the armies'

The noun tägiš 'encounter, collision, hostilities' was also recorded by Gerard Clauson [2: 487]. The use of possessive suffix and the suffix of locative case prove that it is a noun, not a verb. This word also has a verbal homonym: tägiš- 'to fight' [1: 548]. The root of these words is the polysemantic verb täg- with one of its meanings being 'to attack' [2: 476]. We come across with this meaning in Orkhon Inscriptions:

Nä basïn-alım, täg-älim,- tidim (Tonukuk 39)

What be_defeated-IMP.1.PL attack-IMP.1.PL say-PST

'Why should we be defeated, let us attack, said I'

The words tägǐ̌- and tägiš are formed from this meaning.

All of these words have the same meaning: 'war, fight'. However, there is another word with the suffix

$-i \dddot{s}$ :

4. $\ddot{U} k \ddot{u} \breve{s}$ 'many, much'. This word is used in several sentences:

$\ddot{U} k \ddot{u s ̌ s}$ öl-täči an-ta tirilti (Bilge Kaghan east 31)

Many die-FUT that-LOC that-LOC return to life-PST

'Many who will die, returned to life there'

Yabïz bat biz, azï $\quad$ üküs-ig körtig irti, sülätim

tir ermis (Ongin front 7)

Weak bad we few-ACC many-ACC see-PST AUX-PS march-PST-

1.SG say-PRS AUX-PST

'We are weak and bad, we saw few and many, I marched, said he'

This word is from the verb $\ddot{i k}$ - 'to collect, to gather': 
Kälir ersär, $\quad$ kü är $\quad$ ükül-ür (Tonukuk 32)

Come-PRS AUX-COND, noise man gather-PRS

'If he comes, the men will gather because of the noise'

Unlike the other words formed with -ǐs, üküs is not a noun and does not have a reciprocal meaning. It can be accepted as a sign of beginning of the second stage.

The second stage of the development of the suffix -ïs came after the period of Orkhon Turkic. In this stage, a lot of nouns were made of the verbs with this suffix as an analogy of the previous nouns with -ï̌s. -ï̌ began to act as an independent noun forming suffix.

There are a lot of nouns with -ï̌ in Divanu lughat it-turk which do not have any reciprocal meaning, e.g. alqïs 'blessing', qaryïs 'curse', ülüš 'part' [3: 133]. It proves that the language of this written monument belongs to the second stage. The word $\ddot{u}$ lüs 'part' is more important, because it formed after the period of Orkhon Turkic. In the language of Orkhon Inscriptions, the word ülüg is used instead of that word:

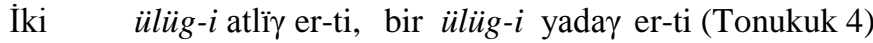

Two part-POSS.3.SG with_horse AUX-PST one part-POSS.3.SGinfantry AUX-PST

'Two parts of them were cavalry, one part was infantry'

It also shows that $-i \check{s}$ then developed as a noun forming suffix, and it became a common derivative suffix, and used instead of -ig.

In the later periods of Turkic language history, the nouns with -ïs was used widely, like oqša $\check{s}$ 'similarity', yügrǚs 'running', olturuš 'assembly' [4: 150]. This process continued in modern Turkic languages: ayanïs 'pity' (ayan- 'to pity'), ökiniš 'sorrow' (ökin- 'to grieve, to sadden'), ötiniš 'proposal' (ötin- 'to ask, to beg') (Karakalpak) [5: 409]; alyǐs 'blessing' (alqa- 'to bless'), ülüš 'part' (üle- 'to divide'), క̌uиaš 'calm' (క̌uиa"to calm down”) (Karachai-Balkar) [6: 142-143]; adǐs 'shot' (Altai); talaš 'quarrel' (Bashkir); soruš 'question', oturuš 'assembly' (Gagauz), kürinišs 'view' (Tatar); tïnǐs ‘breath' (Tuva) [13: 164]; kiriš 'entrance' (Uzbek), örinis 'happyness' (örin- 'to be happy') (Khakas), učuš 'flight' (Kirgiz) [7: 107]; క̌eš 'food' (亏̌e- 'to eat') (Kirgiz), pělterěš 'meaning' (pělter- 'to mean') (Chuvash) [4: 145]; gačĭš 'running', gülü̈̌s 'laughter', gediš 'going', gäliš 'coming', yeriš 'walking' (Azerbaijan), duruš 'standing' (Turkish).

In Orkhon Inscriptions the suffix -ï̌ combines two meanings:

1. Reciprocal action;

2. The name of the process.

However, in the modern Turkic languages, the range of the meanings formed with -iš is much larger:

1. Name of an action being done by two or more people: sox- 'to beat' - soyïs 'fight' (Khakas), qürq'to break, to destroy' - qürqïs 'fight' (Yakut).

2. Name of an action: aračilan- 'to defend' - aračillanïs 'defence', xoptan- 'to complain' - xoptanïs 'complaint' (Khakas). (Khakas).

3. Process of an action: püdir- 'to build' - püdiris 'construction', pïzirr- 'to cook' - pïzïrïs 'cooking' (Azerbaijan).

4. Result of an action: qürbaa- "to cut into pieces" - qürbas 'steak' (Khakas) [8: 67], düzäliš

As it was already mentioned, in some modern Turkic languages including Uighur, Uzbek, Turkmen, Kirgiz, Altai, and Turkish, the suffix -ǐs is more productive, and it can be added to every verb, that's why it is regarded as a suffix of verbal nouns. Nouns with this suffix are similar to infinitive, for instance, keliš 'coming', bičiš 'writing', tipildeš 'beat', učuš 'flight', tasqadïnǐs 'training' (Altai) [9: 671-672]. M.Ergin saw a difference between the nouns with $-i \check{s}$ and other deverbal nouns, and included it to the same row with the suffixes -maq/$m e k$ and -ma/-me. He called them the suffixes of verbal nouns, and noted that they have a meaning not of an object, but work: alïš, gelišs, arayǐ̌s, söyleyišs, oturuš, okuyuš, öksürüš, yürüyüš [10: 187]. It can also be added to the verbs with negative suffix, i.e. bilmeyiš 'not knowing' [11: 117], which is not typical for derivative suffixes. We can call it the third stage of the development of the suffix -iš. In this stage, -iš increased its productivity, began to be added to every verb, and became a suffix of verbal nouns.

\section{FROM DEVERBAL NOUNS TO INFINITIVE}

maq/-mek is the main suffix of infinitive in the modern Turkic languages. However, in the earlier stages of Turkic languages, it did not form infinitive and served as a morpheme making nouns from verbs. It was only used once in Orkhon Inscriptions, in the noun armaq 'lie' which was the base of armaqci 'lier':

...tabyač bodun täbligin kürlig üčün, armaqčisïn ünüün... (Kul Tigin east 6)

...Tabghach people sly cunning for lier-POSS.3.SG for...

'...because Tabghach people were sly and cunning, because they were liers...'

There are a lot of nouns made from verbs by the means of -maq in the Old Turkic language, for example, uqmaq 'mind, wit' (uq- 'to understand'), tüzülmäk 'silence' (tüzül- 'to get right'), tutmaq 'handle' (tut'to catch, to hold') [12: 53]. It is also typical for Divanu lughat it-turk: čaqmaq 'flint', boymaq 'shirt button; 
necklace', qüsmaq 'lasso', toqümaq 'mallet' [3: 132]. But it is not unique for Old Turkic, as this suffix is also used in some modern Turkic languages as a deverbal noun-forming suffix, i.e. qospaq 'combination' (qos- 'to connect'), ̌̌arïspaq 'contest, competition' (̌̌arïs- 'to compete') (Karakalpak) [5: 391]; batmaq 'marsh' (bat- 'to sink') (Karachai-Balkar) [6: 221]; atǐsmaq 'exchange of fire' (atǐš- 'to exchange fire'), üyšmek 'assembly' (üyš'to gather') (Turkmen) [4: 305]; yemäk, čaxmaq (Azerbaijani).

Many turkologists including E.V.Sevortyan assume that the derivative function of the suffix -maq comes before its grammaticalization [4: 221]. The condition of the suffix -maq in most modern Turkic languages, except Azerbaijani and Turkish [13: 159], proves that it was a derivative suffix originally. It also makes the ideas that infinitive was not developed in the early stages of Turkic languages [14: 483], and it is only typical for the languages in Oghuz group [15: 170].

It is from the verb ar- 'to lie, to deceive':

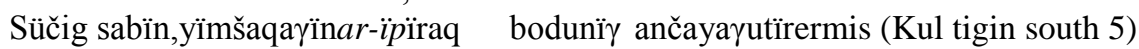

Sweet word-INS valuable gift-INS deceive_CVB far people-ACC that bring_closer-PRSAUX-PST

'They brought closer the people that were far away deceiving them with their sweet words and valuable

gifts'

The noun armaq was registered in the other written monuments as a part of the construction ezük armaq 'lie, mistake' [1: 192].

The use of the derivative suffix $-\check{c} i$ after the suffix $-m a q$ proves that it was a derivative suffix, since derivative suffixes cannot be added after inflective ones.

Another suffix in this category is $-m a /-m e$. This suffix is genetically related to $-m a q /-m e k$, but it is unclear whether -ma comes from -maq, or on the contrary -maq from -ma. This question is not settled yet.

Like -maq, the suffix -ma was also an unproductive derivative suffix in Old Turkic language. In Divanu lughat it-turk, it was used only in few examples, including süzmä 'condensed sour milk', käsmä 'bangs', tügmä 'button' [3: 132]. It started to be used widely in the written monuments of the 14th century [4: 139].

- $m a$ and its phonetic variations are very productive as deverbal noun-forming suffixes in the modern Turkic languages, for instance, dörötpe 'creativity' (döret- 'to make, to create'), aralaspa 'mixed' (aralas- 'to mix'), tapsïrma 'task' (tapsïr- 'to charge'), körsetme 'instruction' (körset- 'to show'), dizbe 'list' (diz- 'to arrange') (Karakalpak) [5: 393]; sürmä 'smoothing plane' (sür- 'to scrub') (Karachai-Balkar) [6: 264]; käyäşmä 'conversation' (Bashkir), doquma 'knitting' (Gagauz), uydirma 'finction' (Uzbek), čarba 'cereals' (Khakas) [13: 163]; birlašma 'combination' (Uzbek), ěs'me 'drink' (Chuvash) [4: 132, 134]; dolma, qovurma 'roast', qazma 'mud-hut' (Azerbaijani), dondurma 'ice-cream', qüzartma 'roast', qüyma (Turkish).

-ma/-me can also act as a synonym of the suffix -maq/-mek in Azerbaijani and Turkish [13: 163] which makes it the suffix of infinitive. It can also be added to the verbs with negative suffix, proving that it has inflectional function, instead of a derivational one. dubious.

There are only two nouns formed with the suffix -ma/-me, though the origin of the second one is

Yelmä 'intelligence group':

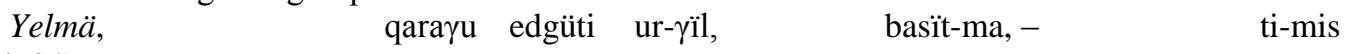

(Tonukuk 34)

Intelligence_group guard well beat-IMP.2.SG be_defeated-NEG say-PST

'Set up the intelligence groups and guards well, do not be defeated, said he'

This noun is from the verb yel- 'to gallop, to go fast' [1:254]:

Kün yämä, tün yämä yel-ü bar-dï-mïz (Tonukuk 27)

Day too night too gallop-CVB go-PST-1.SG

'We went galloping day and night'

Yalma 'cloth, cloak':

Yaraq-ïn-ta yalma-sïn-ta yüz artuq oq-un

ur-tï... (Kul Tigin east 33)

Weapon-POSS.3.SG-LOC

shoot-PST

cloth-POSS.3.SG-LOC hundred more arrow-INS

'He shot more than hundred arrows to his weapons and cloths'

For Sir Gerard Clauson, the root of this noun is the verb *yal- which also occurred in yalïy and yalt 'bare, naked' [2: 918, 922, 929]. There is also the verb yalïn- 'to undress' [1: 229] which can be considered as the reflexive voice of *yal-. Although there is phonetic similarity in these words, the semantic relation is not clear.

\section{CONCLUSION}

Grammaticalization of the derivative suffixes is possible for the Turkic languages, just as the lexicalization of the inflectional ones. While the reason of the transformation from inflection to derivation is 
petrifying of the grammatical form as an independent word, the main reasons of the change from derivation to inflection is increase in the productivity of the suffix. As a suffix begins to be added to every word from the same class, its derivational meaning disappears and turns into a grammatical one. This is a common process in the suffixes of verbal nouns, infinitives and participles, and the earliest traces of this process in the Turkic languages belong to the language of Orkhon Inscriptions.

There is also another opinion on this matter which claims the similarity of the functions of inflectional and derivational suffixes in the earliest texts of the Turkic languages [16: 5]. It is proved with the examples given from Orkhon Inscriptions.

\section{REFERENCES}

[1] Nadelyayev V.M. et al. (Eds.). Drevnetyurkskiy slovar' (Leningrad: Nauka, 1969).

[2] Clauson G. An etymological dictionary of pre-thirteenth-century Turkish (Oxford: Clarendon Press, 1972).

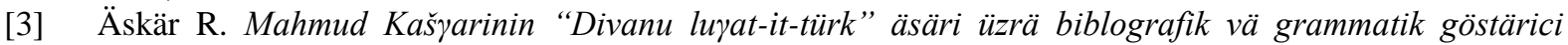
(Baku: MBM, 2008).

[4] Sevortyan E.V. Affiksï imennogo slovoobrazovaniya v azerbayžanskom yazïke: opït sravnitel'nogo issledovaniya. Moskva: Nauka, 1966.

[5] Baskakov N.A. Karakalpakskiy yazïk. Tom II. Fonetika i morfologiya. Čast' pervaya. Časti reči I slovobrazovaniye (Moskva: Izdatel'stvo AN SSSR, 1952).

[6] Khabičev M.A. Karačayevo-balkarskoye imennoye slovoobrazovaniye (Čerkessk, 1971).

[7] Serebrennikov B.A., Gadjiyeva N.Z. Sravnitel'no-istoričeskaya grammatika tyurkskix yazikov (Baku: Maarif, 1979).

[8] Tarakanova I.M. Slovoobrazovaniye imen sušestvitel'nïx v xakasskom yazïke (v sopostavitel'nom aspekte) (Xakasskoe kniznoe izdatel'stvo, 2008).

[9] Tïdikkova, Nadejda. Ob osobennostyax imeni deystviya v altayskom yazïke, Turkish Studies, Vol 2/2, 2007, 665-679.

[10] Ergin M. Türk dil bilgisi (İstanbul: Bayrak, 2013).

[11] Kononov A.N. Grammatika sovremennogo turetskogo literaturnogo yazïka (Moskva-Leningrad: Izdatel'stvo Akademii Nauk SSR, 1956).

[12] Gabain A. von. Eski Türkčenin Grameri. Translated by M.Akalin (Ankara: Türk Tarih Kurumu Basimevi, 1988).

[13] Scherbak A.M. Očerki po sravnitel'noy morfologii tyurkskix yazïkov: imya (Leningrad: Nauka, 1977).

[14] Tenishev E.R. (Ed.) Sravnitel'no-istoričeskaya grammatika tyurkskix yazikov. Morfologiya (Moskva: Nauka, 1988).

[15] Dmitriyev N.K. Grammatika baškirskogo yazïka (Moskva-Leningrad: Izdatel'stvo Akademii Nauk SSSR, 1948).

[16] Bašdaš,Cahit.Türkčedeüčüncügrup(araekler),http://turkoloji.cu.edu.tr/DILBILIM/cahit_basdas_ara_ekler. pdf. 